\title{
Detecting Schistosoma Haematobium Infection by Microscopy and Polymerase Chain Reaction (Pcr) In School Children In The Three Senatorial Districts of Cross River State, Nigeria
}

\section{Rosemary Kaiso Esiere}

University of Calabar Teaching Hospital

Emmanuel onyekachukwu Ibeneme

University of Calabar

Emmanuel Offiong Effanga

University of Calabar

Edema Enogiomwan Imalele ( $\sim$ edemaeddy@gmail.com )

University of Calabar https://orcid.org/0000-0003-3774-5121

Miracle Kaiso Esiere

University of Calabar

Paul Columba Inyang-Etoh

University of Calabar

Ambrose Anyanwu Alaribe

University of Calabar

\section{Research Article}

Keywords: schistosomiasis, microscopy, PCR, school-age children, Nigeria, Cross River State

Posted Date: May 28th, 2021

DOI: https://doi.org/10.21203/rs.3.rs-560563/v1

License: (9) This work is licensed under a Creative Commons Attribution 4.0 International License.

Read Full License

Version of Record: A version of this preprint was published at Journal of Parasitic Diseases on September 2nd, 2021. See the published version at https://doi.org/10.1007/s12639-021-01446-2. 


\section{Abstract}

As a result of the poor sensitivity and specificity of the standard parasitological diagnostic methods currently being used, this study was conducted to compare the standard parasitological diagnostic methods and Polymerase Chain Reaction (PCR) in determining the prevalence of urinary schistosomiasis in Cross River State (CRS). The study was conducted between April 2015 and March 2016. Seven hundred and seventy seven (777) urine samples were randomly collected from selected school-age children. The urine samples were subjected to standard parasitological and molecular examinations. Chisquare test was used to test the differences between the data on subgroups and the results from specimen examinations. An overall prevalence of $1.7 \%$ was recorded using microscopy and $34.7 \%$ recorded using PCR. The highest prevalence of infection by microscopy occurred in the Southern Senatorial District (2.3\%), while the Northern Senatorial District recorded the highest prevalence of infection by PCR $(53.2 \%)(p<0.05)$. Males were more infected $(2.4 \%)$ than females $(0.6 \%)$ using microscopy. With PCR, males were also more infected $(35.7 \%)$ compared to females $(33.3 \%)(p<0.05)$. The highest prevalence of infection using microscopy and PCR both occurred in school-age children aged 5-8 years (3.6\% and $47.8 \%$ respectively), while the lowest prevalence for both methods occurred in participants aged $17-20$ years ( $0 \%$ for both methods) $(p<0.05)$. This study has shown PCR to be effective in detecting schistosomiasis infection and also re-affirms the endemicity of urinary schistosomiasis in the three Senatorial Districts of CRS.

\section{Introduction}

Schistosomiasis is a worldwide problem afflicting about 249 million persons and $97 \%$ of the infected persons reside in Africa (Anazaku et al. 2017). Approximately 779 million people are at risk of being infected in 76 endemic countries globally, $85 \%$ of these reside on the African continent (Utzinger et al. 2009). Every year schistosomiasis is responsible for about 1.7 million disability adjusted life years (DALYs) (Chitsulo et al. 2000). Schistosoma mansoni and S. haematobium cause intestinal and urinary schistosomiases respectively in many African countries where they may occur concurrently. Schistosomiasis causes health, labour loss, hypertension and significant reduction in socioeconomic benefits, particularly, late complications such as irreversible urinary tract obstruction and risk of renal failure are often associated with urinary schistosomiasis (King, 2009).

Control programmes for schistosomiasis are mainly founded on treating of infected people, hence adequate-case finding is essential. Hitherto, the existing protocols for the diagnosis of schistosomiasis are search for ova of the schistosomes in urine or stool samples and detection of ova or adult worm antigens in sera and urine of infected persons. Detecting antigens of ova or adult worm in sera/urine of diseased persons can distinguish current infections from past ones with almost $100 \%$ specificity. Egg counts and haematuria are the only parameters presently employed in surveillance. However, Poggensee et al. (1998) reported the presence of morbidity of the urinary tract in some women who were schistosomiasis-infected in Tanzania who had scanty or no egg output and no haematuria. This implies that there is need for methods of detection with more specificity and sensitivity of the disease in humans. 
Several studies have looked at the prevalence and intensity of $S$. haematobium in communities in Nigeria using methods like the detection of haematuria and ova in urine (Okon et al. 2009, 2010; Adie et al. 2013). Though they are useful in the detection of heavy infections, their low sensitivity in detecting light/early infections is a drawback that cannot be overlooked. As a result of the poor specificity and sensitivity of the standard parasitological diagnostic methods currently being used, the real estimate of the prevalence of schistosomiasis in sub-Saharan endemic areas of Africa is not clear (Hotez and Fenwick, 2009). Earlier studies have shown that detection of schistosomal parasite-specific DNA can be done in urine of persons who are infected (Lodh et al. 2013). Adult schistosome worms are the source of DNA because they shed teguments at regular intervals. Therefore if parasite-specific DNA is detected in urine it confirms the parasites' presence (Ibironke et al. 2012). In recent years, multiple authors have demonstrated Schistosome parasite-specific DNA in urine (Lodh et al. 2013). This study, therefore, sought to compare microscopy and PCR in the characterization of S. haematobium in Cross River State (CRS), Nigeria.

\section{Materials And Methods}

\section{Study area and population}

This study was carried out in Cross River State with Calabar as the capital. The state is divided into three Senatorial Districts (North, South and Central) with 18 Local Government Areas (LGAs). Samples were collected from Central, Southern and Northern Senatorial Districts and were analysed at the University of Calabar Teaching Hospital (UCTH), Calabar and Molecular Biology Laboratory, Niger Delta University, Bayelsa State. The study population consisted of children/adolescents aged 5-20 years attending primary and secondary schools in the study area.

\section{Ethical consideration}

Subjects for this study were enrolled after approval was sought and obtained from Ministry of Health Ethical Committee, Cross River State (REC No.: RP/REC/2016/423). The village heads were informed of the study through advocacy visits to their palaces and local school authorities. Written informed consent was obtained from parents/guardians of participants.

\section{Sampling and sample size determination}

Seven hundred and seventy seven (777) samples were randomly obtained from children/adolescents in secondary/primary schools in the study area. Selection of children from schools in the study area was done randomly by picking one out of every four pupil within the range of the study.

\section{Sample collection}

The study was conducted between April 2015 and March 2016. Seven hundred and seventy seven (777) clean appropriately labelled universal containers were issued to the randomly selected children for collection of urine samples. The urine samples from these individuals were used for parasitological/molecular examinations. Subjects were instructed to include the last drops of urine 
(Cheesbrough, 2005). The samples were collected between $10.00 \mathrm{am}$ and $2.00 \mathrm{pm}$, on each collection day to ensure maximum yield of schistosome eggs (Cheesbrough, 2005). All samples collected were preserved with 2 drops of $10 \%$ formalin in $25 \mathrm{~mL}$ capacity (WHO, 2003) and transported to the parasitology laboratory, University of Calabar Teaching Hospital.

\section{Parasitological examination}

A modified filtration system adopted by Useh and Ejezie, (1999) was used. Briefly a funnel holding a What-man No. 1 filter paper was suspended on a conical flask to act as the filtration system. $10 \mathrm{~mL}$ of the urine sample was filtered for the eggs of Schistosoma. The thoroughly agitated sample was allowed to pass through the filtration system. Using a blunt-ended forceps, the filter paper was removed with great care and placed on a slide. The filter paper was placed upwards (eggs on surface) on the slide using $\times 10$ objective, with the condenser iris closed adequately to give a good contrast. A systematic examination of the entire filter paper was conducted for $S$. haematobium ova. Any urine sample with ova was recorded as positive. The number of eggs counted was recorded per $10 \mathrm{ml}$ of urine samples collected.

\section{Molecular examination for schistosome infection}

\section{Urine cell pellet preparation}

The urine sample was spun at 5,000 rpm for $10 \mathrm{~min}$, the supernatant decanted and cell pellets washed thrice with $25 \mathrm{~mL}$ phosphate buffer saline $\left(0.8 \% \mathrm{NaCl}, 2.7 \mathrm{mM} \mathrm{KCl}, 1.8 \mathrm{mM} \mathrm{KH}_{2} \mathrm{PO} 4,8 . \mathrm{mM} \mathrm{Na}_{2} \mathrm{HPO} 4 \mathrm{pH}\right.$ 7.4). These were immediately stored at $-80^{\circ} \mathrm{C}$ until used.

\section{Genomic DNA extraction from urine cell pellet}

The urine cell-pellets were re-suspended using $150 \mu \mathrm{L}$ of DNA elution buffer, then transferred into individual Eppendorf tubes, followed by $200 \mu \mathrm{L}$ bio-fluid - cell buffer solution (red) and $20 \mu \mathrm{L}$ proteinase K enzyme to digest the sample. Vortexing was done to have a thorough mix, and then incubated at $55^{\circ} \mathrm{C}$ for 10 minutes on a heating block. Exactly $420 \mu \mathrm{L}$ of genomic binding buffer was added to the digested sample and mixed thoroughly. The mixture was then transferred to a Zymo-Spin IIC - XL column in a collection tube and centrifuged at 14,000 rpm for one minute. The columns were then placed in new collection tubes, where $400 \mu \mathrm{L}$ DNA of pre-wash buffer was added and spun for one minute at 14,000 rpm and the collection tubes emptied. Seven hundred $(700 \mu \mathrm{L}) \mathrm{g}$-DNA wash buffer was then added and spun at 14,000 rpm for one minute, and the collection tube emptied again. Furthermore, $200 \mu \mathrm{L}$ of $\mathrm{g}$-DNA wash buffer was added and centrifuged again at 14,000 rpm for one minute and the collection tube discarded with the flow through. The columns were transferred to clean micro-centrifuge tubes and $50 \mu \mathrm{L}$ of DNA elution buffer was added, incubated at room temperature for 5 minutes, and then spun at 14,000 rpm for one minute to elute the DNA. Finally, the columns were discarded and the g-DNA, already extracted in the micro-centrifuge tubes, stored at $-20^{\circ} \mathrm{C}$ until further use for PCR reactions.

\section{DNA quantification}


NanoDrop ND-1000 spectrophotometer (NanoDrop Technologies, California, USA) was used to determine the quantity and purity of DNA. The equipment was initialized and blanked before readings. DNA concentrations of the samples were recorded, in $\mathrm{ng} / \mu \mathrm{L}$ while the absorbance $260 / 280$ was used to determine the purity. Samples with absorbance ranging from 1.70 to 2.10 were selected for amplification by PCR.

\section{Amplification of Schistosoma haematobium DNA repeat fragment from urine samples}

Polymerase chain reaction was carried out on all the 13 positive samples and 108 negative samples, respectively, by microscopy, using $0.4 \mu \mathrm{L}$ of species-specific primers ShDra1 F (forward: 5 '-

GATCTCACCTATCAGACGAAAC-3' and ShDra1 R (reverse: 5'-T CACAACGATACGACCAAC-3'), which were previously designed by Hamburger et al., (2001) for specific amplification of 121 bp Dra1 tandem repeats of $S$. haematobium. Amplification reactions were carried out in $20 \mu \mathrm{L}$ volume. Two microlitre $(2 \mu \mathrm{L})$ of DNA (concentration: 4-6ng/ $\mu \mathrm{L}$ ) served as PCR template in the reaction volume, $10 \mu \mathrm{L}$ of $2 X$ Quick-Load Mastermix containing $200 \mu \mathrm{M}$ of dNTPs, $1.5 \mu \mathrm{M}$ of Taq polymerase (Inqaba Biotech, Johannesburg, South Africa) and $1.5 \mu \mathrm{M}$ of $\mathrm{MgCl}$. The PCR conditions were as follows: initial denaturation at $95^{\circ} \mathrm{C}$ for 5 minutes, followed by 30 cycles of denaturation at $95^{\circ} \mathrm{C}$ for one minute, annealing at $55^{\circ} \mathrm{C}$ for 90 seconds and extension at one minute at $72^{\circ} \mathrm{C}$ for 5 minutes.

\section{Agarose gel electrophoreses}

One gram and half $(1.5 \mathrm{gm})$ of agarose powder was measured and poured in $100 \mathrm{ml}$ of 1 X TBE buffer (Tris Boric Ethylene diamine Tetra-acetic acid.) then heated in a microwave for 5 minutes to allow the agarose powder dissolve and make a clear solution. It was allowed to cool and $4 \mu \mathrm{L}$ of ethidium bromide was added. The solution was poured in an electrophoretic casting tray, the comb was placed and then the solution was allowed to cool and solidified for about 30 minutes then placed in an electrophoresis tank. Exactly $10 \mu \mathrm{L}$ of PCR product was pipetted, already mixed with DNA loading dye, and then loaded in the agarose gel lane after removing the comb. DNA ladder and negative control were also loaded and the gel was subjected to an electric field at $120 \mathrm{~V}$ for 25 minutes. The gel was visualized on a UV trans-illuminator for band detection.

\section{Data analysis}

All analyses were performed using the SPSS package (version 22). Descriptive statistical analysis was used to calculate the prevalence and intensity of infections. Chi-square test was used to test the differences between the data on subgroups and the results from specimen examinations. Differences were considered significant at a $p$-value less than $0.05(p<0.05)$.

\section{Results}

Seven hundred and seventy seven (777) school children/adolescents randomly selected from eight schools in the three Senatorial Districts of Cross River State were screened to determine the current status 
of urinary schistosomiasis in these districts. The Northern Senatorial District had the highest number of participants $(348 / 777 ; 44.8 \%)$ followed by the Southern Senatorial District $(220 / 777 ; 28.6 \%)$ and the Central Senatorial District $(209 / 777 ; 26.9 \%)$. The school children/adolescents also comprised of 450 $(57.9 \%)$ males and $327(42.1 \%)$ females. The age distribution of the participants in the study was 5-8 years $(248 / 777 ; 31.9 \%), 9-12$ years $(339 / 777 ; 43.6 \%), 13-16$ years $(116 / 777 ; 14.9 \%)$ and $17-20$ years (74/777; $9.5 \%)$.

Table 1 shows the prevalence of $S$. haematobium infection by microscopy and PCR in the Senatorial Districts. The highest prevalence of infection by microscopy occurred in the Southern Senatorial Districts (2.3\%), while the Northern Senatorial District recorded the highest prevalence of infection by PCR (53.2\%); there was a statistically significant difference $(p<0.05)$ in the prevalence of infection in the Senatorial Districts using microscopy and PCR.

Table 2 shows the prevalence of $S$. haematobium infection by microscopy and PCR with respect to gender. Males were more infected than females using microscopy ( $2.4 \%$ for males and $0.6 \%$ for females) and PCR (35.7\% for males and 33.3\% for females); there was a statistically significant difference in prevalence of infection by gender, using microscopy and PCR $(p<0.05)$.

Table 3 shows the prevalence of $S$. haematobium infection by microscopy and PCR in participants with respect to age. The highest prevalence of infection using PCR occurred in participants aged 5-8 years (47.8\%), while the lowest prevalence occurred in participants aged 17-20 years (0\%). Using microscopy, the highest and lowest prevalence occurred in age groups $5-8$ years $(3.6 \%)$ and $17-20$ years $(0 \%)$. There was a statistically significant difference $(p<0.05)$ in the prevalence of infection among the different agegroups using microscopy and PCR.

Table 1

Prevalence of Schistosoma haematobium infection by microscopy and PCR by Senatorial Districts

\begin{tabular}{|lllllll|}
\hline $\begin{array}{l}\text { Senatorial } \\
\text { District }\end{array}$ & $\begin{array}{l}\text { No. } \\
\text { Examined by } \\
\text { microscopy }\end{array}$ & $\begin{array}{l}\text { No. (\%) positive } \\
\text { by microscopy }\end{array}$ & $\begin{array}{l}\text { Number } \\
\text { examined by } \\
\text { PCR }\end{array}$ & $\begin{array}{l}\text { Number(\%) } \\
\text { positive by } \\
\text { PCR }\end{array}$ & $\chi^{2}$ & $\begin{array}{l}p \text { value } \\
\text { South }\end{array}$ \\
220 & $5(2.3)$ & 31 & $5(16.1)$ & 11.082 & 0.004 \\
\hline Central & 209 & $1(0.5)$ & 46 & $14(30.4)$ & & \\
\hline North & 348 & $7(2.0)$ & 44 & $23(52.3)$ & \\
\hline Total & 777 & $13(1.7)$ & 121 & $42(34.7)$ & \\
\hline
\end{tabular}


Table 2

Prevalence of Schistosoma haematobium infection by microscopy and PCR by gender

\begin{tabular}{|lllllll|}
\hline Gender & $\begin{array}{l}\text { No. } \\
\text { examined } \\
\text { by } \\
\text { microscopy }\end{array}$ & $\begin{array}{l}\text { No. (\%) positive by } \\
\text { microscopy }\end{array}$ & $\begin{array}{l}\text { No. examined } \\
\text { by PCR }\end{array}$ & $\begin{array}{l}\text { No. (\%) } \\
\text { positive by } \\
\text { PCR }\end{array}$ & $\chi^{2}$ & $\begin{array}{l}p \text { - } \\
\text { value }\end{array}$ \\
\hline Males & 450 & $11(2.4)$ & 70 & $25(35.7)$ & 0.257 & 0.012 \\
\hline Females & 327 & $2(0.6)$ & 51 & $17(33.3)$ & \\
\hline Total & 777 & $13(1.7)$ & 121 & $42(34.7)$ & \\
\hline
\end{tabular}

Table 3

Prevalence of $S$. haematobium infection by microscopy and PCR of subjects examined by age

\begin{tabular}{|lllllll|}
\hline $\begin{array}{l}\text { Age group } \\
\text { (years) }\end{array}$ & $\begin{array}{l}\text { No. } \\
\text { Examined } \\
\text { by } \\
\text { microscopy }\end{array}$ & $\begin{array}{l}\text { No. (\%) } \\
\text { positive by } \\
\text { microscopy }\end{array}$ & $\begin{array}{l}\text { No. Examined } \\
\text { by PCR }\end{array}$ & $\begin{array}{l}\text { No. (\%) positive } \\
\text { by PCR }\end{array}$ & $\chi^{2}$ & $\begin{array}{l}p \text { - } \\
\text { value }\end{array}$ \\
\hline $5-8$ & 248 & $9(3.6)$ & 46 & $22(47.8)$ & 8.106 & 0.044 \\
\hline $9-12$ & 339 & $3(0.9)$ & 58 & $18(31.0)$ & \\
\hline $13-16$ & 116 & $1(0.9)$ & 13 & $2(15.4)$ & \\
\hline $17-20$ & 74 & $0(0.0)$ & 4 & $0(0.0)$ & \\
\hline Total & 777 & $13(1.7)$ & 121 & $42(34.7)$ & \\
\hline
\end{tabular}

Plate 1 shows an agarose gel electrophoresis of the amplified repeats of Schistosoma haematobium from positive samples by microscopy. Lane 1, 2, and 10 are negative samples, Lanes 39, 11-13 represents positive samples with 1 to 3 repeats. $M$ is a 100bp ladder. Lane 14 represents the negative control.

Plate 2 shows an agarose gel electrophoresis showing the amplified repeats of the Schistosoma haematobium from selected samples negative by microscopy. Lanes showing 1 band or more represent positive samples for $S$. haematobium while lanes with no bands represent negative samples. $L$ is $100 \mathrm{bp}$ ladder.

\section{Discussion}

Studies have compared different diagnostic procedures used to detect schistosomiasis. These include tests for specific antibody, circulating antigens, haematuria, egg detection and ultrasound scans of the urinary tract. Nonetheless, it is difficult to find a "gold" standard because of the variability of the diagnostic performance of these techniques especially in areas with variable prevalence of $S$. 
haematobium infection (Koukounari et al. 2009). However, assays based on polymerase chain reaction (PCR) have recently begun to show potentials as effective methods in detecting DNA of parasites in urine and saliva (Mharakurwa et al. 2006).

In this study, the $121 \mathrm{bp}$ Dra1 tandem repeat PCR developed by Hamburger and colleagues (Hamburger et al. 2001) was adapted to detect $S$. haematobium DNA in urine. The Dra1 fragments were detected in samples from both children and adolescents when ova of schistosome were detected, and also in specimens where no ova were detected. However, these fragments were not detected in some of the samples. Out of the 777 urine samples, $13(1.7 \%)$ were positive by microscopy, but PCR showed that 42 $(34.7 \%)$ out of 121 randomly selected samples showed parasite-specific DNA for $S$. haematobium. This speaks volume of the sensitivity of PCR over microscopy. This agrees with results reported by Gasmelseed et al. (2014).

The overall prevalence (1.7\%) recorded from parasitological examination of urine sample is lower than that reported for Cross River State (CRS) in earlier studies. Ejezie et al. (1991) established a schistosomiasis prevalence value of $43.5 \%$ in Adim, CRS, while Useh and Ejezie (1996) recorded a prevalence of $53.8 \%$ in the same study area. Ekanem et al. (1995) recorded a prevalence of $44 \%$ in ljiman, Yakurr Local Government Area (LGA), a community close to Adim. Recent studies have shown that the urinary schistosomiasis prevalence in Adim community increased from 53.8\% reported by Useh and Ejezie (1996) to 57.4\% (Okon et al. 2009). In Adim, Etim et al. (2012) reported a 42.2\% prevalence of urinary schistosomiasis, while Okon et al. $(2007,2009)$ reported $35 \%$ and $45.3 \%$ prevalence rates respectively from parasitological examination of urine samples. The present study has re-affirmed the endemicity of S. haematobium in the three Senatorial Districts; Southern (Biase LGA), Central (Yakurr LGA) and Northern (Bekwarra LGA). According to Useh (2013), the extensive, unrestrained and unchecked increase in irrigation, water impoundment schemes, and widespread ignorance of schistosomiasis in the majority of the endemic areas have elevated the disease to a very serious health predicament in the subSaharan part of the continent, including Nigeria. This disease is also considered as one of the most frequently occurring parasitic infections globally (Okon et al. 2007). In CRS, the agrarian population and suitable conditions that enable the snail intermediate host to thrive has added to the prevalence of schistosomiasis (Ejezie et al. 1991).

It is likely that the reduction in prevalence and intensity of urinary schistosomiasis recorded in these communities, is as a result of treatments carried out by previous researchers; Okon et al. (2010), evaluated the status of urinary schistosomiasis in Ogoja LGA, where he went ahead to treat infected persons with Artesunate and found $64 \%$ cure rate while Inyang-Etoh et al. (2004) had a $70 \%$ cure rate in their work in Adim, CRS, using Artesunate. Another work, in Adim, recorded a cure rate of $88 \%$ after utilizing Artesunate and Praziquantel combination (Inyang-Etoh et al. 2009). This reduction in morbidity of urinary schistosomiasis could also be as a result of the integrated health interventions introduced about eight years ago by the Neglected Tropical Diseases Control Unit in collaboration with the schistosomiasis/soil transmitted helminths unit of the Federal Ministry of Health, CRS, in November 2012 (Adie et al. 2015). Integrated control measures put in place included chemotherapy of infected individuals 
with Praziquantel and health education on the predisposing factors responsible for the transmission of urinary schistosomiasis (Adie et al. 2015).

Infection pattern varied according to gender with more male participants $(11 ; 2.4 \%)$ being infected than females $(2 ; 0.6 \%)$. This difference varied significantly at $(p<0.05)$. Similar findings were reported in other studies (Inyang-Etoh et al. 2004; Ugbomoiko et al. 2010). This difference may be explained by the fact that males are more involved in water contact activities than females due to social inhibitions like being restricted from activities such as fishing, public bathing and swimming (Etim et al. 2012). However, this deviates from other studies that reported no significant difference in gender-related prevalence. Okon et al. (2007), Bala et al. (2012) and Morenikeji et al. (2014) all reported both genders to be equally at risk.

Prevalence of $S$. haematobium varied significantly across age groups with the least $(0 \%$ for both microscopy and PCR methods) and highest (3.6\% for microscopy and $47.8 \%$ for PCR) recorded in age group 17-20 and 5-8 years, respectively ( $\$ \bowtie 0.05$ ). This is similar to previous result reported in Biase and Yakurr LGAs by Adie et al. (2015), but disagrees with other findings which recorded highest infection rates occurring in age brackets 12-15 (Morenikeji et al. 2014) and 10-14 (Ugbomoiko et al. 2010 and Deribe et al. 2011). The prevalence of urinary schistosomiasis varied with age in this study which is in contrast to findings reported by Ekwunife et al. (2009), while it was supported by Sam-Wobo et al. (2009) and Uwazuoke et al. (2009).

\section{Conclusion}

This study has re-affirmed the endemicity of urinary schistosomiasis in the three Senatorial Districts of CRS. The prevalence of $34.7 \%$ recorded in this study is still within the WHO recommended threshold of $\geq$ $20 \%$, for mass drug administration (MDA). This study has shown that PCR is more sensitive than standard parasitological methods for the diagnosis of $S$. haematobium infection.

\section{Declarations}

\section{Acknowledgements}

The authors wish to thank the staff of the University of Calabar Teaching Hospital (UCTH), Calabar and Molecular Biology Laboratory, Niger Delta University, Bayelsa State, for their assistance during the course of this study

\section{Funding}

The authors did not receive support from any organization for the submitted work.

\section{Conflicts of interest}

The authors declare no conflict of interest exist. 
Availability of data and material

Not applicable

\section{Code availability}

Not applicable

\section{Authors' contributions}

Esiere, Rosemary Kaiso: Conceptualization, Data curation, Investigation, Methodology, Writing - original drafting. Ibeneme, Emmanuel Onyekachukwu: Investigation, Methodology, Writing - review and editing. Imalele, Edema Enogiomwan: Methodology, Writing - review and editing. Effanga, Emmanuel Offiong: Data curation, Methodology. Esiere, Miracle Kaiso: Investigation, Data curation. Inyang-Etoh, Paul Columba: Formal analysis, Project administration, Validation. Alaribe, Ambrose Andrew Anyanwu: Conceptualization, Validation, Supervision

\section{Ethics approval}

Subjects for this study were enrolled after approval was sought and obtained from Ministry of Health Ethical Committee, Cross River State.

\section{Consent to participate}

The village heads were informed of the study through advocacy visits to their palaces and local school authorities. Written informed consent was obtained from parents/guardians of participants.

\section{References}

Adie HA, Oyo-Ita A, Okon OE, Arong GA, Ating IA, Braide El, Nebe O, Emanghe UE, Otu, AA (2015) Evaluation intensity of urinary schistosomiasis in Biase and Yakurr Local Government Area of Cross River State, Nigeria, after two years of Integrated Control Measures. Res J Parasitology 10:58-65.

Adie HA, Okon OE, Arong, GA, Braide El, Ekpo UF (2013) Spatial distribution of urinary schistosomiasis in Cross River State, Nigeria, using geographical information system and school based questionnaire. Pakistan J Bio Sci 16:1166 - 1172.

Anzaku AA, Oche OD, Ishaku A, Ishaku A (2017) Prevalence of urinary schistosomiasis and water contact activities as risk factor in Wowyen community. J Ann Toxicology Applications 1(1):7-10.

Bala AY, Ladan MU, Mainasara M (2012) Prevalence and intensity of urinary Schistosomiasis in Abarma village, Gusau, Nigeria: a preliminary investigation. Science World J 7(2):1-4.

Cheesbrough M (2005) District laboratory practice in Tropical countries. (2ndedn) Tropical Health Technology, London. 
Chitsulo L, Engels D, Montresor A, Savioli L (2000) The global status of schistosomiasis and its control. Acta Tropica,77: 41-51.

Deribe K, Eldaw A, Hadziabduli S, Kailie E, Omer MD, Mohammed AE, Jamshed T, Mohammed EA, Mergani A, Ali GA, Babikir K, Adem A, Hashim F (2011) High prevalence of urinary schistosomiasis in two communities in South Darfur: implication for interventions. Parasites and Vectors. 4(14):1-5.

Ejezie GC, Uko IE, Braide El (1991) Schistosomiasis in Cross River State, Nigeria: Prevalence and intensity of infection in Adim, Akamkpa Local Government Area. J Hyg Epidemiol Microbiol Immunol 35:141-147.

Ekanem EE, Ejezie GC, Asindi AA, Antia-Obong OE (1995) Urinary symptoms and blood pressure of children with Schistosoma haematobium infection in South-Eastern Nigeria. East African Med J 72:486489 .

Ekwunife CA, Agbor VO, Ozumba AN, Eneanya Cl, Ukaga CN (2009) Prevalence of urinary schistosomiasis in lyede-Ame community and environ in Ndokwa East Local Government Area, Delta State, Nigeria. Nig J Parasitol 30:27-31.

Etim SE, Okon OE, Oku EE, Ukpong Gl, Ohioma ME, Uttah CE (2012) Urinary schistosomiasis in a ricefarming community in Biase Area of Cross River State. Nig J Parasitol 33: 197-201.

Gasmelseed N, Karamino NE, Abdelwahed MO, Hamdoun AO, Elmadani AE (2014) Genetic diversity of Schistosoma haematobium parasite IS NOT associated with severity of disease in epidemic area in Sudan. Bio Med Central Infect Dis, 14:469.

Hamburger J, He N, Abbasi I, Ramzy RM, Jourdane J, Ruppel A (2001) Polymerase chain reaction assay based on a highly repeated sequence of Schistosoma haematobium: A potential tool for monitoring Schistosome-infested water. Am J Trop Med Hyg 65:907-911.

Hotez PJ, Fenwick A (2009) Schistosomiasis in Africa: An Emerging Tragedy in Our New Global Health Decade. Plos Negl Trop Dis 3(9):485.

Ibironke O, Koukounari A, Asaolu S, Moustaki I, Shiff C (2012) Validation of a new test for Schistosoma haematobium based on detection of Dra1 DNA fragments in urine: evaluation through latent class analysis. Pub Lib Sci Negl Trop Dis 6:e1464.

InyangEtoh PC, Essien UC, Amama M, Useh F (2004) Prevalence of urinary schistosomiasis among school in Ukwolo - Obudu and Abini communities in Cross River State, Nigeria. Port-Harcourt Med J 3:13.

Inyang-Etoh PC, Ejezie GC, Useh MF, Inyang-Etoh EC (2009) Efficacy of a combination of Praziquantel and Artesunate in the treatment of urinary schistosomiasis in Nigeria. Trans R Soc Trop Med Hyg 103:38-44.

King CH (2009) Toward the elimination of schistosomiasis. New England J Med 360 (2):106-109. 
Koukounari A, Webster JP, Donnelly CA, Bray BC, Naples J, Bosompem K, Shiff C (2009) Sensitivities and Specificities of diagnostic tests and infection prevalence of Schistosoma haematobium estimated from data on adults in villages Northwest of Accra, Ghana. Am J Trop Med Hyg 80:435-441.

Lodh N, Mwansa JCL, Mutengo MM, Shiff CJ (2013) Diagnosis of Schistosoma mansoni without the Stool: Comparison of Three Diagnostic Tests to Detect Schistosoma mansoni Infection from Filtered Urine in Zambia. Am Soc Trop Med Hyg 89: 46-50.

Mharakurwa S, Simoloka C, Thuma PE, Shiff CJ, Sullivan DJ (2006) PCR detection of Plasmodium falciparum in human urine and saliva samples. Malaria J 5:103.

Morenikejji O, Quazim J, Omoregie C, Hassan A, Nwuba R, Anumudu C, Adejuwon S, Salawu O, Jegede A, Odaibo A (2014) A Cross sectorial study on urogenital schistosomiasis in children, haematuria in an endemic rural area of Nigeria. Afri Health Sci, 14(2): 390-396.

Okon OE, Udoutun MF, Oku EE, Nta Al, Etim SE, Abraham JJ, Akpan PA (2007) Prevalence of urinary schistosomiasis in Abini community, Biase local government area, Cross river State, Nigeria. Nig J Parasitol 28(1):28-31.

Okon OE, Ememayom A, Opara K (2009) Reliability of self-reported blood in urine for diagnosis of Schistosoma haematobium in a community in South-Eastern Nigeria. The Internet J Epidemiol 7(2).

Okon OE, Obi A, Opara K (2010) The efficacy of Artesunate in the treatment of urinary schistosomiasis in Ogoja, Cross River State, Nigeria. Internet J Trop Med 6(2).

Poggensee G, Kiwelu I, Saria M, Richter J, Krantz I, Feldmeir H (1998) Schistosomiasis of the lower reproductive tract without egg excretion in urine Am J Trop Med Hyg 59: 782-783.

Sam-Wobo SO, Ekpo UF, Ameh IG, Osileye OT (2009) Continued high endemicity of urinary schistosomiasis in Ogun State, Nigeria. Nig J Parasitol 30(1):48-52.

Ugbomoiko US, Ofoezie IE, Okoye IC, Heukelbach J (2010) Factors associated with uriinary schistosomiasis in two Peri-urban communities in South- Western Nigeria. Ann Trop Med Parasitol 104(5): 409-419.

Useh MF, Ejezie GC (1996) Prevalence and morbidity of S. haematobium infection in Adim community of Nigeria. JMedical Lab Sci 5:10-15.

Useh MF, Ejezie GC (1999) Modification of behaviour and attitude in the control of schistosomiasis. 1. Observations on water-contact patterns and perceptions of infection. Ann Trop Med Parasitol 93(7):711720.

Useh MF (2013). Parasitic diseases-schistosomiasis. Creative Commons Attribution License, Geneva, Switzerland, pp: 82-83. 
Utzinger J, Raso G, Brooker S, De Savigny D, Tanner M, Ornbjerg N, Singer BH, N'goran EK (2009)

Schistosomiasis and neglected tropical diseases: towards integrated and sustainable control and a word of caution. Parasitology 136:1859-1874.

Uwaezuoke JC, Anosike JC, Udujih OS (2009) Endemicity of urinary schistosomiasis in Mbaitoli Local Government Area of Imo State, Nigeria. Nig J Parasitol 30:18-22.

World Health Organization. (2003). Determination of sample size for researches. 1-24.

\section{Figures}

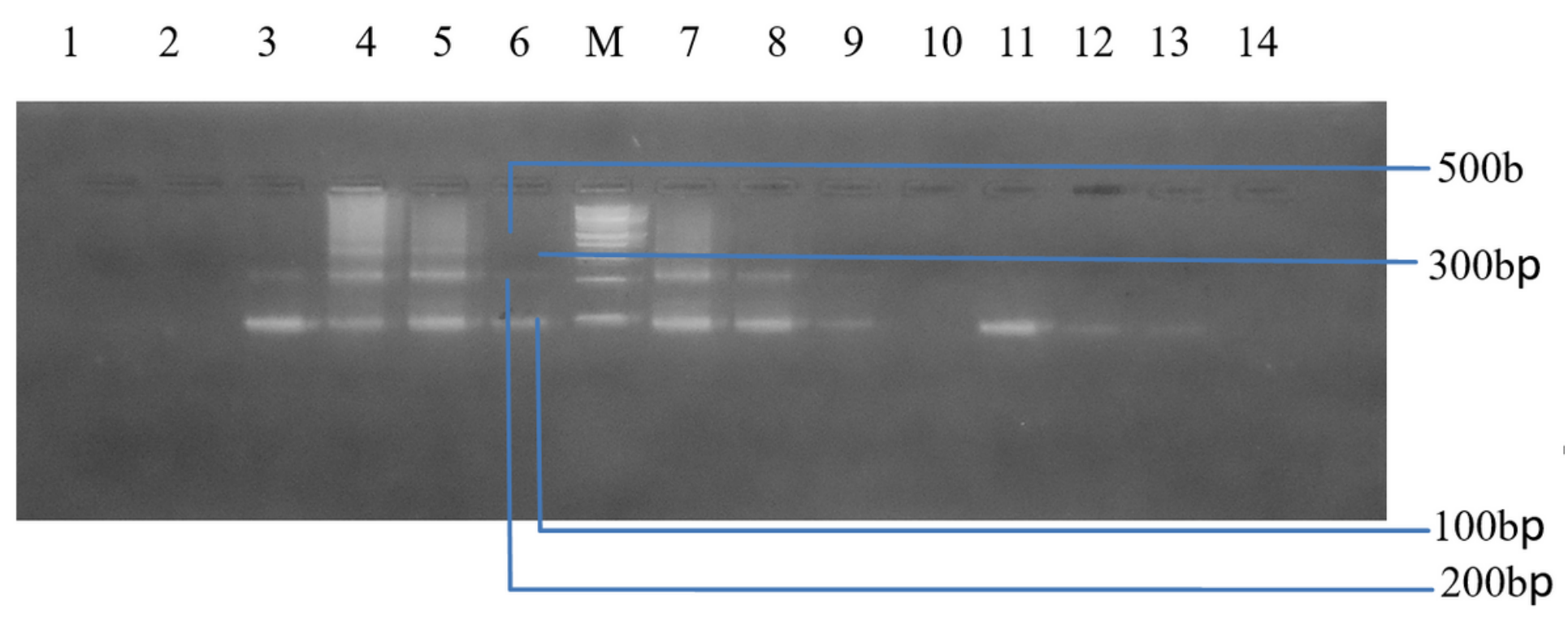

\section{Figure 1}

Plate 1: Agarose gel electrophoresis showing the amplified repeats of the Schistosoma haematobium from the positive samples by microscopy. Lane 1, 2 and 10 are negative samples. Lanes 11-13 represents positive samples with 1 to 3 repeats. $M$ is a 100bp ladder. Lane 14 represents the negative control 


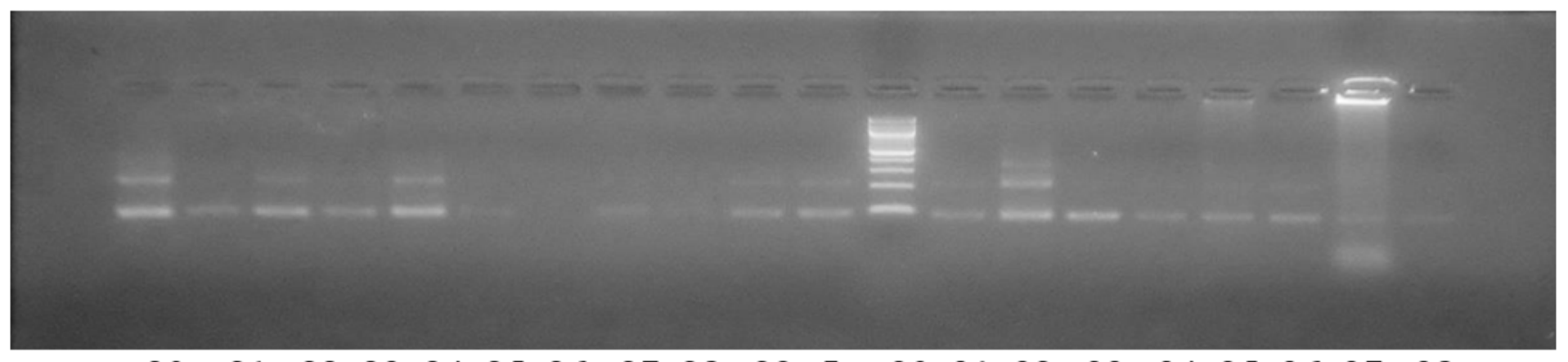

$\begin{array}{llllllllllllllllllll}20 & 21 & 22 & 23 & 24 & 25 & 26 & 27 & 28 & 29 & \mathrm{~L} & 30 & 31 & 32 & 33 & 34 & 35 & 36 & 37 & 38\end{array}$

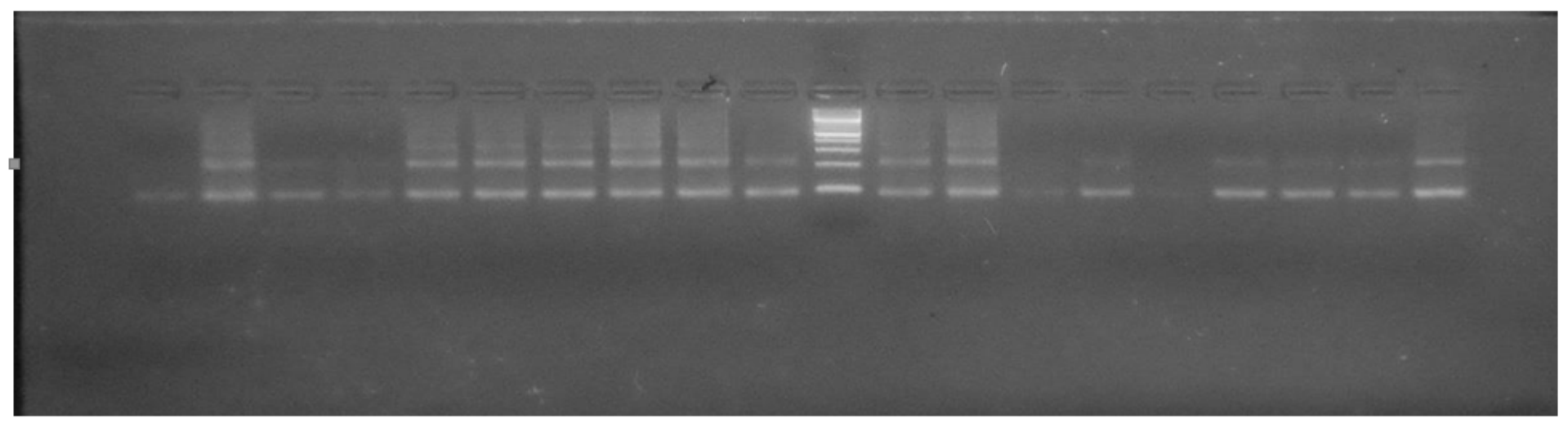

Figure 2

Plate 2: Agarose gel electrophoresis showing the amplified repeats of the Schistosoma haematobium from selected samples negative by microscopy. Lanes showing 1 band or more represent positive samples for $S$. haematobium while lanes with no bands represent negative samples. $L$ is a $100 \mathrm{bp}$ ladder. 